\title{
Quantum Chemical Calculation of Molecular and Periodic Peptide and Protein Structures
}

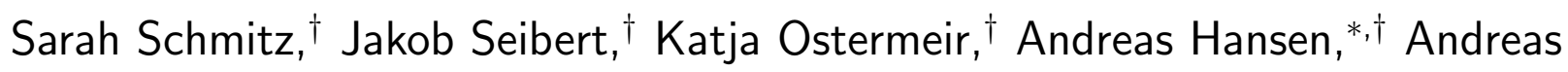

H. Göller, ${ }^{\ddagger}$ and Stefan Grimme ${ }^{*, \dagger}$

$\dagger$ Mulliken Center for Theoretical Chemistry, Institut für Physikalische und Theoretische

Chemie der Universität Bonn, Beringstr. 4, D-53115 Bonn

$\ddagger$ Bayer AG, Pharmaceuticals, R\&BD, Computational Molecular Design, D-42096 Wuppertal

E-mail: hansen@thch.uni-bonn.de; grimme@thch.uni-bonn.de

Phone: +49 (0)228 7360431; +49 (0)228 732351 


\section{Supporting Information Available}

\section{Geometrical descriptors}

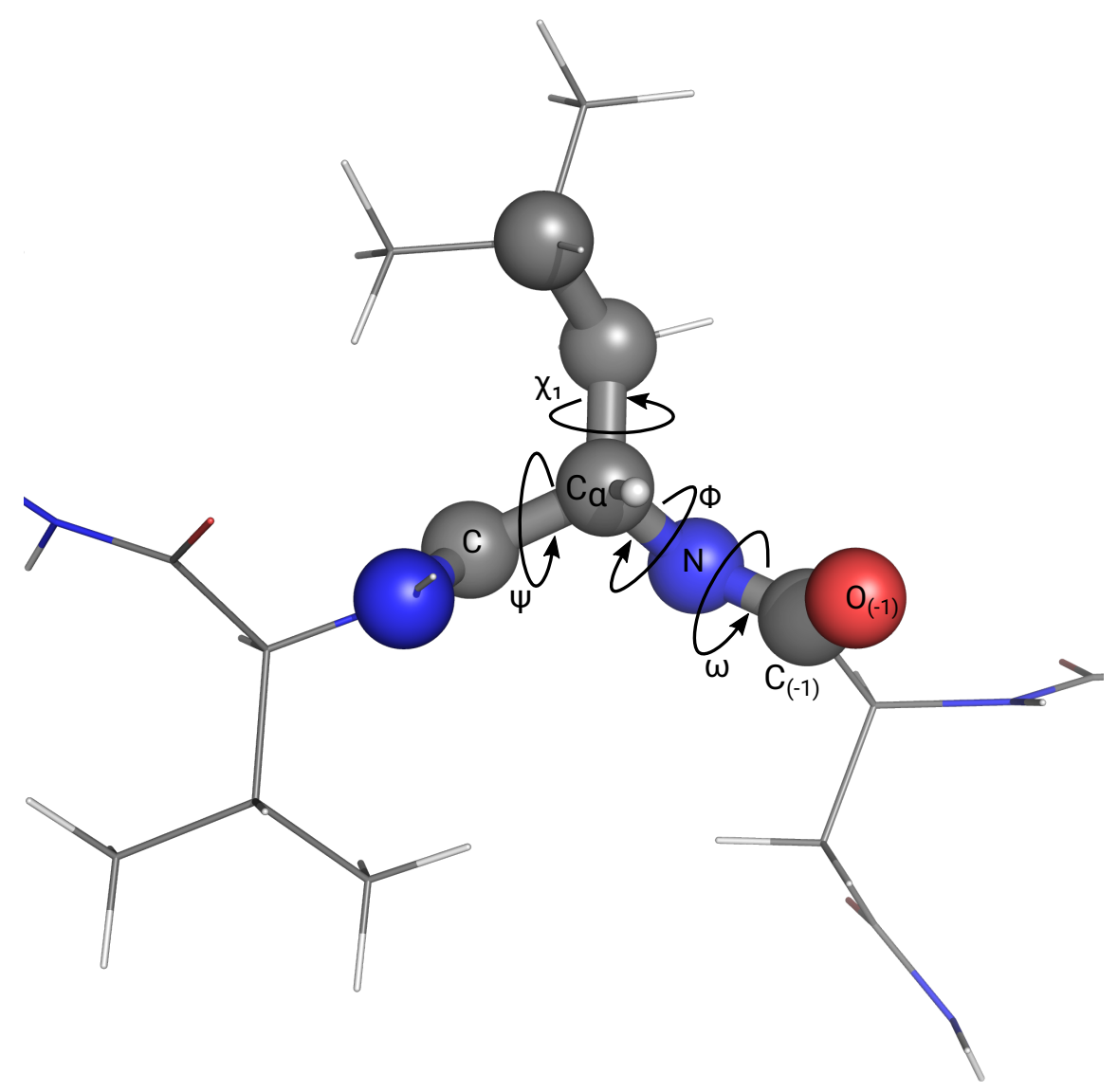

Figure S1: Depiction of the four dihedral angles discussed in this work. $\Phi, \Psi$ and $\omega$ are backbone angles, whereas $\chi_{1}$ is the first side chain angle. 


\section{Periodic optimizations}

Table S1: Properties of peptides of the subset of 10 protein fibrils of the periodic optimizations including the number \# of atoms (after neutralizing) and residues (res).

\begin{tabular}{lcc}
\hline PDB entry & \#atoms & \#res \\
\hline 3SGS & 90 & 6 \\
4R0U & 90 & 7 \\
3FPO & 90 & 6 \\
3Q2X & 93 & 6 \\
3FVA & 96 & 6 \\
3NVG & 97 & 6 \\
3FTK & 100 & 7 \\
1YJP & 107 & 7 \\
2OMM & 107 & 7 \\
2Y29 & 109 & 6 \\
\hline
\end{tabular}

Table S2: $\mathrm{C}_{\alpha}$ RMSDs of the subset of 10 peptides (in $\AA$ ) with respect to experimental X-ray structure. $\mathrm{PBC}=$ periodic boundary conditions, mol. = molecular

\begin{tabular}{lccc}
\hline & \multicolumn{3}{c}{$\mathrm{C}_{\alpha}$ RMSD with respect to experiment } \\
& sHF-3c, PBC & sHF-3c, mol. & HF-3c, mol. \\
\hline 1YJP & 0.23 & 0.36 & 0.41 \\
3NVG & 0.34 & 0.59 & 0.62 \\
3FPO & 0.27 & 0.73 & 0.73 \\
2OMM & 0.24 & 0.36 & 0.41 \\
3FVA & 0.25 & 0.37 & 0.43 \\
3Q2X & 0.28 & 0.69 & 0.64 \\
4R0U & 0.63 & 1.00 & 1.01 \\
3FTK & 0.49 & 0.71 & 0.89 \\
2Y29 & 0.58 & 0.45 & 0.57 \\
3SGS & 0.97 & 0.30 & 0.32 \\
\hline \multicolumn{5}{c}{} \\
\hline
\end{tabular}

\section{First Test Set}

All molecular optimizations conducted with GFNn-xTB converged without problems, showing the intrinsic robustness of the xTB methods. The OPLS2005 optimization did not converge for the protein 2FRG and the AMBER* optimization failed for 2PNE, in both cases 
due to a failure of the internal Maestro optimizer. For HF-3c, all optimization converged without problems, too. Hence, to arrive at an unbiased statistics, the initial test set was limited to a subset of 70 systems, for which converged structures could be obtained with all tested methods.

Table S3: Properties of proteins and peptides of the first test set including the number \# the number of atoms and residues(res), charges, the percentage of secondary structure as $\alpha$-helix, $\beta$-strand, and unstructured loop region, the class of a peptide and protein as well as the $\mathrm{X}$-Ray resolution.

\begin{tabular}{|c|c|c|c|c|c|c|c|c|}
\hline $\begin{array}{l}\text { PDB } \\
\text { entry }\end{array}$ & \#atoms & \#res & charge & helix & strand & loop & class & X-Ray res \\
\hline $4 Q X X$ & 70 & 5 & 0 & 0 & 0 & 100 & protein fibril & 1.45 \\
\hline 3DG1 & 76 & 6 & 0 & 0 & 0 & 100 & protein fibril & 1.66 \\
\hline $3 \mathrm{FTR}$ & 76 & 6 & 0 & 0 & 0 & 100 & protein fibril & 1.61 \\
\hline 3SGS & 88 & 6 & -2 & 0 & 0 & 100 & protein fibril & 1.7 \\
\hline $4 \mathrm{R} 0 \mathrm{U}$ & 90 & 7 & 0 & 0 & 0 & 100 & protein fibril & 1.38 \\
\hline $3 \mathrm{FPO}$ & 91 & 6 & 1 & 0 & 0 & 100 & protein fibril & 1.5 \\
\hline $3 \mathrm{Q} 2 \mathrm{X}$ & 94 & 6 & 1 & 0 & 0 & 100 & protein fibril & 1.45 \\
\hline $3 \mathrm{FVA}$ & 96 & 6 & 0 & 0 & 0 & 100 & protein fibril & 1.46 \\
\hline $4 \mathrm{R} 0 \mathrm{~W}$ & 96 & 7 & 0 & 0 & 0 & 100 & protein fibril & 1.5 \\
\hline $3 \mathrm{NVG}$ & 98 & 6 & 1 & 0 & 0 & 100 & protein fibril & 1.48 \\
\hline $4 \mathrm{NIP}$ & 98 & 7 & 0 & 0 & 0 & 100 & protein fibril & 1.9 \\
\hline $3 \mathrm{FTK}$ & 100 & 7 & 0 & 0 & 0 & 100 & protein fibril & 1.5 \\
\hline 1YJP & 107 & 7 & 0 & 0 & 0 & 100 & protein binding & 1.8 \\
\hline 2OMM & 107 & 7 & 0 & 0 & 0 & 100 & protein fibril & 2 \\
\hline $2 Y 29$ & 110 & 6 & 1 & 0 & 0 & 100 & protein fibril & 2.3 \\
\hline $4 \mathrm{RIK}$ & 122 & 9 & 0 & 0 & 0 & 100 & lipid binding protein & 1.85 \\
\hline 3SGO & 183 & 11 & 0 & 0 & 0 & 100 & protein fibril & 2.56 \\
\hline
\end{tabular}




\begin{tabular}{|c|c|c|c|c|c|c|c|c|}
\hline 3FTL & 200 & 14 & 0 & 0 & 0 & 100 & protein fibril & 1.6 \\
\hline $1 \mathrm{EDN}$ & 328 & 21 & -2 & 14 & 0 & 86 & vasoconstrictor & 2.18 \\
\hline $3 \mathrm{E} 4 \mathrm{H}$ & 386 & 29 & 0 & 0 & 24.1 & 75.9 & plant protein & 1.8 \\
\hline $4 \mathrm{BFH}$ & 426 & 30 & -1 & 0 & 13.3 & 86.7 & hydrolase inhibitor & 1.25 \\
\hline $4 \mathrm{NCU}$ & 432 & 27 & -1 & 0 & 29.6 & 70.4 & viral protein & 1.11 \\
\hline $1 \mathrm{GCN}$ & 471 & 29 & 0 & 44.8 & 0 & 55.2 & hormone & 3 \\
\hline $4 \mathrm{GIF}$ & 727 & 45 & 1 & 82.2 & 0 & 17.8 & transport protein & 2.8 \\
\hline $4 \mathrm{OZK}$ & 733 & 49 & 0 & 0 & 55.1 & 44.9 & toxin & 2.04 \\
\hline $2 \mathrm{OVO}$ & 812 & 56 & 0 & 17.9 & 14.3 & 67.9 & $\begin{array}{l}\text { proteinase inhibitor } \\
\text { (kazal) }\end{array}$ & 1.5 \\
\hline $1 \mathrm{UOY}$ & 854 & 64 & 1 & 0 & 25 & 75 & exudate protein & 1.5 \\
\hline 3LE4 & 870 & 55 & 1 & 0 & 16.4 & 83.6 & nuclear protein & 1.7 \\
\hline $3 \mathrm{HON}$ & 889 & 55 & 1 & 9.1 & 32.7 & 58.2 & protein binding & 3 \\
\hline $4 \mathrm{E} 5 \mathrm{R}$ & 896 & 56 & 2 & 0 & 16.1 & 83.9 & RNA binding protein & 1.9 \\
\hline $1 \mathrm{I} 2 \mathrm{~T}$ & 967 & 61 & 0 & 80.3 & 0 & 19.7 & ligase & 1.04 \\
\hline 1EGP & 990 & 61 & -1 & 18 & 0 & 82 & proteinase inhibitor & 2 \\
\hline 1MJC & 1009 & 69 & -1 & 0 & 37.7 & 62.3 & $\begin{array}{l}\text { transcription regula- } \\
\text { tion }\end{array}$ & 2 \\
\hline 1L2P & 1012 & 61 & 2 & 95.1 & 0 & 4.9 & hydrolase & 1.55 \\
\hline 3DSP & 1044 & 66 & 1 & 0 & 47 & 53 & metal binding protein & 2.2 \\
\hline 1OAI & 1055 & 68 & -1 & 51.5 & 0 & 48.5 & nuclear transport & 1 \\
\hline 1YU5 & 1077 & 67 & 0 & 41.8 & 0 & 58.2 & structural protein & 1.4 \\
\hline $1 \mathrm{HYP}$ & 1090 & 75 & -2 & 45.3 & 0 & 54.7 & $\begin{array}{l}\text { hydrophobic seed pro- } \\
\text { tein }\end{array}$ & 1.8 \\
\hline 1UTG & 1116 & 70 & -1 & 65.7 & 0 & 34.3 & steroid binding & 1.34 \\
\hline $1 \mathrm{ZVA}$ & 1116 & 75 & -1 & 85.3 & 0 & 14.7 & viral protein & 1.5 \\
\hline IAIL & 1130 & 70 & 3 & 84.3 & 0 & 15.7 & RNA binding protein & 1.9 \\
\hline
\end{tabular}


2EVB 1158

$74 \quad 0$

0

37.8

62.2 lipid binding protein, 1.55

transferase

$\begin{array}{lllllllll}\text { 1KIV } & 1192 & 78 & 1 & 0 & 15.4 & 84.6 & \text { kringle } & 2.1\end{array}$

$\begin{array}{lllllllll}3 \mathrm{~B} 7 \mathrm{H} & 1196 & 76 & 0 & 60.5 & 0 & 39.5 & \text { structural protein } & 2\end{array}$

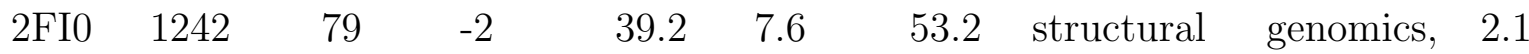

$\begin{array}{llllllll}4 \text { KMC } & 1249 & 79 & 1 & 87.3 & 0 & 12.7 & \text { transcription }\end{array}$

$\begin{array}{lllllllll}\text { 1VCC } & 1264 & 77 & 0 & 13 & 28.6 & 58.4 & \text { DNA binding } & 1.6\end{array}$

$\begin{array}{lllllllll}4 \mathrm{LHF} & 1271 & 79 & 1 & 45.6 & 0 & 54.4 & \text { viral protein } & 2.4\end{array}$

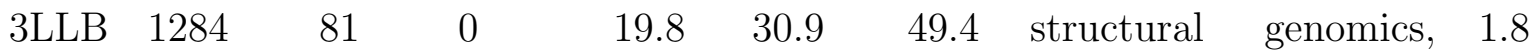

unknown function

$\begin{array}{lllllllll}2 \text { CKX } & 1342 & 83 & 0 & 63.9 & 0 & 36.1 & \text { nuclear protein } & 1.9\end{array}$

$\begin{array}{lllllllll}\text { IULR } & 1368 & 87 & 0 & 26.4 & 35.6 & 37.9 & \text { hydrolase } & 1.3\end{array}$

$\begin{array}{lllllllll}3 \mathrm{H} 8 \mathrm{Y} & 1374 & 95 & -2 & 34.7 & 31.6 & 33.7 & \text { structural protein } & 2.51\end{array}$

$\begin{array}{llllllllll}2 \text { YX5 } & 1387 & 82 & -1 & 29.3 & 14.6 & 56.1 & \text { structural } & \text { genomics, } & 2.3\end{array}$

unknown functions

$\begin{array}{lllllllll}4 \mathrm{E} 6 \mathrm{~S} & 1392 & 85 & 2 & 49.4 & 0 & 50.6 & \text { transcription } & 1.85\end{array}$

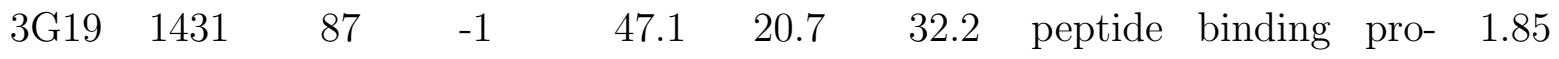

$\begin{array}{lllllllll}3 \text { MX7 } & 1441 & 90 & 2 & 0 & 65.6 & 34.4 & \text { apoptosis } & 1.76\end{array}$

$\begin{array}{lllllllll}\text { 4X3H } & 1463 & 88 & 0 & 39.8 & 0 & 60.2 & \text { signaling protein } & 2.4\end{array}$

$\begin{array}{lllllllll}1 \mathrm{~A} 68 & 1468 & 87 & 2 & 26.4 & 19.5 & 54 & \text { potassium channels } & 1.8\end{array}$

$\begin{array}{lllllllll}\text { 1DSL } & 1472 & 88 & 0 & 5.7 & 38.6 & 55.7 & \text { eye lens protein } & 1.55\end{array}$

$\begin{array}{lllllllll}\text { 4OAJ } & 1494 & 99 & 1 & 14.1 & 34.3 & 51.5 & \text { protein binding } & 2.3\end{array}$

$\begin{array}{lllllllll}\text { 3Q2C } & 1514 & 96 & 0 & 5.2 & 33.3 & 61.5 & \text { immune system } & 2.5\end{array}$

$\begin{array}{lllllllll}\text { 4DJG } & 1538 & 96 & 0 & 77.1 & 0 & 22.9 & \text { protein binding } & 1.9\end{array}$

$\begin{array}{lllllllll}\text { 5F70 } & 1562 & 103 & 2 & 0 & 44.7 & 55.3 & \text { immune system } & 1.8\end{array}$ 


\begin{tabular}{lllllllll} 
1CQY & 1584 & 99 & 2 & 0 & 46.5 & 53.5 & hydrolase & 1.95 \\
1AAJ & 1604 & 105 & -2 & 0 & 40 & 60 & electron transport & 1.8 \\
3RJP & 1610 & 96 & 0 & 35.4 & 16.7 & 47.9 & DNA binding protein & 1.5 \\
1WWB 1616 & 103 & 0 & 0 & 49.5 & 50.5 & transferase & 2.1 \\
4PQD & 1625 & 105 & 0 & 10.5 & 24.8 & 64.8 & protein binding & 1.33 \\
1RIS & 1647 & 97 & 1 & 25.8 & 38.1 & 36.1 & ribosomal protein & 2 \\
1BET & 1657 & 107 & 2 & 0 & 58.9 & 41.1 & growth factor & 2.3 \\
\hline
\end{tabular}

Table S4: Average deviations of four types of dihedral angles (in degree) for the first test set as well as average $\mathrm{C}_{\alpha}$ and heavy atoms RMSD (in $\AA$ ) in each case with respect to the crystal structure.

\begin{tabular}{l|cccc|cc} 
& \multicolumn{4}{|c|}{ angles / } & \multicolumn{2}{c}{ RMSD / $\AA$} \\
& $\Delta \Phi$ & $\Delta \Psi$ & $\Delta \chi_{1}$ & $\Delta \omega$ & $\mathrm{C}_{\alpha}$ & heavy atoms \\
\hline HF-3c & 14.84 & 16.35 & 11.44 & 5.08 & 0.88 & 1.17 \\
GFN2-xTB & 14.19 & 14.65 & 10.06 & 5.41 & 0.59 & 0.87 \\
AMBER* & 19.80 & 15.30 & 12.13 & 5.01 & 0.69 & 0.97 \\
OPLS2005 & 12.42 & 12.25 & 10.69 & 4.60 & 0.58 & 0.84
\end{tabular}

\section{Comparison of GFN2-xTB to PM6-D3H4X and PM7}

We compare optimizations conducted with GFN2-xTB, PM6-D3H4X, and PM7 for 20 proteins and peptides of the first test set (see Table S5). Due to technical problems, we restricted the comparison between the PM methods and GFN2-xTB to a subset of 20 smaller peptides for which the PM calculations were computationally feasible. For the systems 3SGO, both PM methods could not achieve self-consistence, and additionally for 4NCU PM6-H3D4X and for 1GCN PM7 failed during the SCF calculation. For most of the systems, however, MOPAC's COSMO implementation restricted the system size to maximal 426 atoms, as an error due to COSMO occurred otherwise. 
Table S5: Properties of the 20 proteins and peptides of the first test set including the number \# the number of atoms and residues(res), charges, the percentage of secondary structure as $\alpha$-helix, $\beta$-strand, and unstructured loop region, the class of a peptide and protein as well as the $\mathrm{X}$-Ray resolution.

\begin{tabular}{|c|c|c|c|c|c|c|c|c|}
\hline title & \#atoms & \#res & charge & helix & strand & loop & class & X-Ray res \\
\hline 4QXX & 70 & 5 & 0 & 0 & 0 & 100 & protein fibril & 1.45 \\
\hline 3DG1 & 76 & 6 & 0 & 0 & 0 & 100 & protein fibril & 1.66 \\
\hline $3 \mathrm{FTR}$ & 76 & 6 & 0 & 0 & 0 & 100 & protein fibril & 1.61 \\
\hline 3SGS & 88 & 6 & -2 & 0 & 0 & 100 & protein fibril & 1.7 \\
\hline $4 \mathrm{R} 0 \mathrm{U}$ & 90 & 7 & 0 & 0 & 0 & 100 & protein fibril & 1.38 \\
\hline $3 \mathrm{FPO}$ & 91 & 6 & 1 & 0 & 0 & 100 & protein fibril & 1.5 \\
\hline $3 \mathrm{Q} 2 \mathrm{X}$ & 94 & 6 & 1 & 0 & 0 & 100 & protein fibril & 1.45 \\
\hline $3 \mathrm{FVA}$ & 96 & 6 & 0 & 0 & 0 & 100 & protein fibril & 1.46 \\
\hline $4 \mathrm{R} 0 \mathrm{~W}$ & 96 & 7 & 0 & 0 & 0 & 100 & protein fibril & 1.5 \\
\hline $3 \mathrm{NVG}$ & 98 & 6 & 1 & 0 & 0 & 100 & protein fibril & 1.48 \\
\hline $4 \mathrm{NIP}$ & 98 & 7 & 0 & 0 & 0 & 100 & protein fibril & 1.9 \\
\hline $3 \mathrm{FTK}$ & 100 & 7 & 0 & 0 & 0 & 100 & protein fibril & 1.5 \\
\hline 1YJP & 107 & 7 & 0 & 0 & 0 & 100 & protein binding & 1.8 \\
\hline 2OMM & 107 & 7 & 0 & 0 & 0 & 100 & protein fibril & 2 \\
\hline $2 \mathrm{Y} 29$ & 110 & 6 & 1 & 0 & 0 & 100 & protein fibril & 2.3 \\
\hline 4RIK & 122 & 9 & 0 & 0 & 0 & 100 & lipid binding protein & 1.85 \\
\hline 3FTL & 200 & 14 & 0 & 0 & 0 & 100 & protein fibril & 1.6 \\
\hline $1 \mathrm{EDN}$ & 328 & 21 & -2 & 14 & 0 & 86 & vasoconstrictor & 2.18 \\
\hline $3 \mathrm{E} 4 \mathrm{H}$ & 386 & 29 & 0 & 0 & 24.1 & 75.9 & plant protein & 1.8 \\
\hline $4 \mathrm{BFH}$ & 426 & 30 & -1 & 0 & 13.3 & 86.7 & hydrolase inhibitor & 1.25 \\
\hline
\end{tabular}


PM6-D3H4X takes about 3 seconds per optimization step, PM7 2.6 seconds per step and GFN2-xTB 0.38 seconds per step for this subset (average number of atoms: 143). Figure S2 additionally shows, that GFN2-xTB is for most of the geometrical descriptors better than both tested PM methods. Only for the first side chain angle $\chi_{1}$ and for $\omega$, GFN2-xTB is slightly worse than both PM methods. Thus, it can be concluded that GFN2-xTB is faster and more accurate as the tested PM methods.

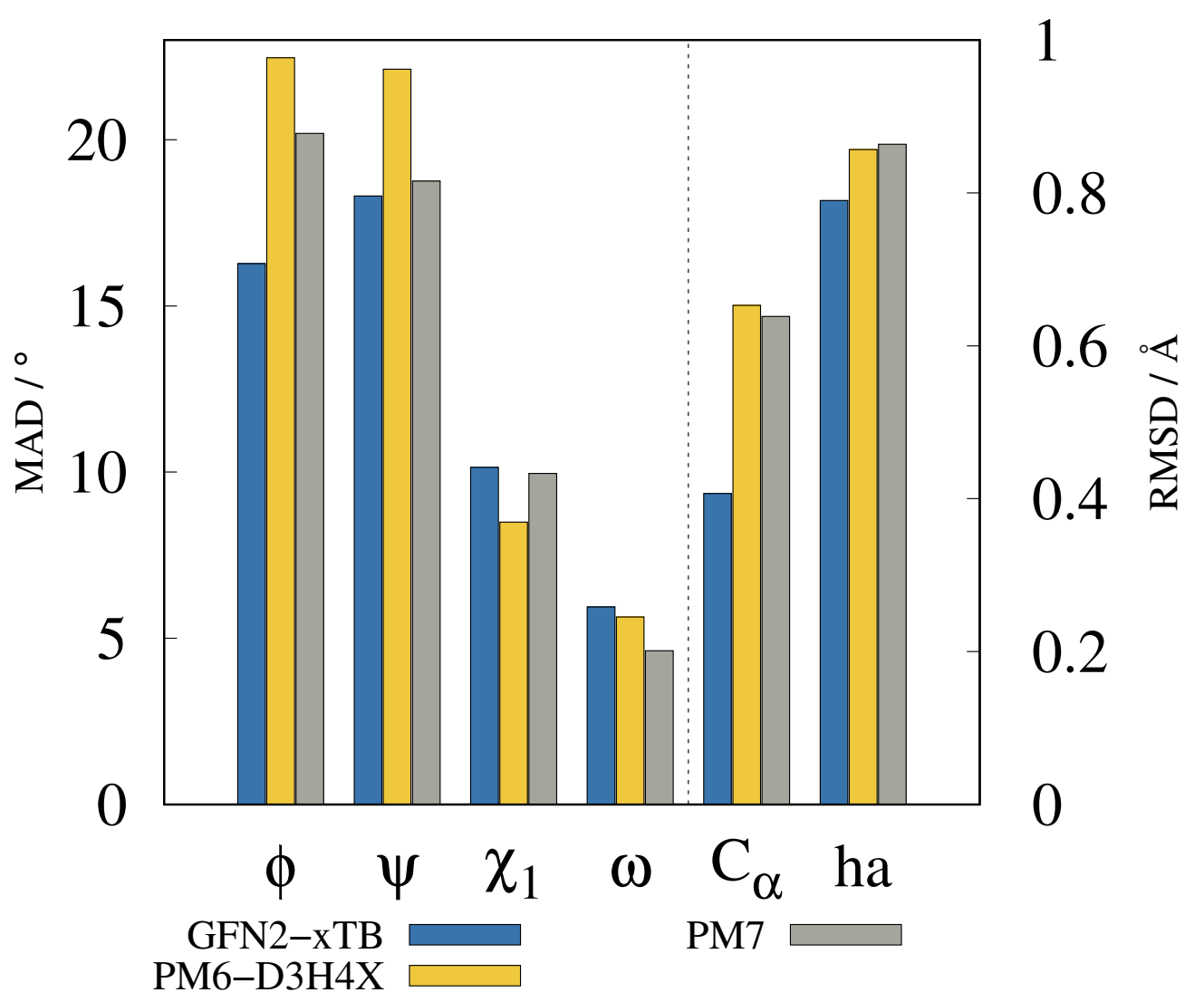

Figure S2: Average deviations of four types of dihedral angles for the subset for the PM methods with respect to the crystal structure.

Table S6: Average deviations of four types of dihedral angles for the subset for the PM methods with respect to the crystal structure.

\begin{tabular}{ccccccc}
\hline & $\Phi_{\text {exp-calc }}$ & $\Psi_{\text {exp-calc }}$ & $\chi_{\text {exp-calc }}$ & $\omega_{\text {exp-calc }}$ & $\operatorname{RMSD}\left(\mathrm{C}_{\alpha}\right.$ & $\operatorname{RMSD}\left(\mathrm{C}_{\text {heavy }}\right)$ \\
\hline PM6-D3H4X & 22.46 & 22.12 & 8.49 & 5.64 & 0.65 & 0.86 \\
PM7 & 20.19 & 18.75 & 9.96 & 4.63 & 0.64 & 0.86 \\
GFN2-xTB & 16.27 & 18.31 & 10.15 & 5.94 & 0.41 & 0.79 \\
\hline
\end{tabular}




\section{Second Test Set Data}

The GFN2-xTB optimization showed convergence problems for the calcium containing protein 1OOJ. Therefore, we conducted a FOD analysis ${ }^{1}$ to check whether artificial static correlation effects are present. ${ }^{2}$ The optimization of 1 OOJ failed due to an internal error occurred, which can be traced back to a bad initial structure (spurios too close O-H contact) that is also visible in the respective FOD plot.

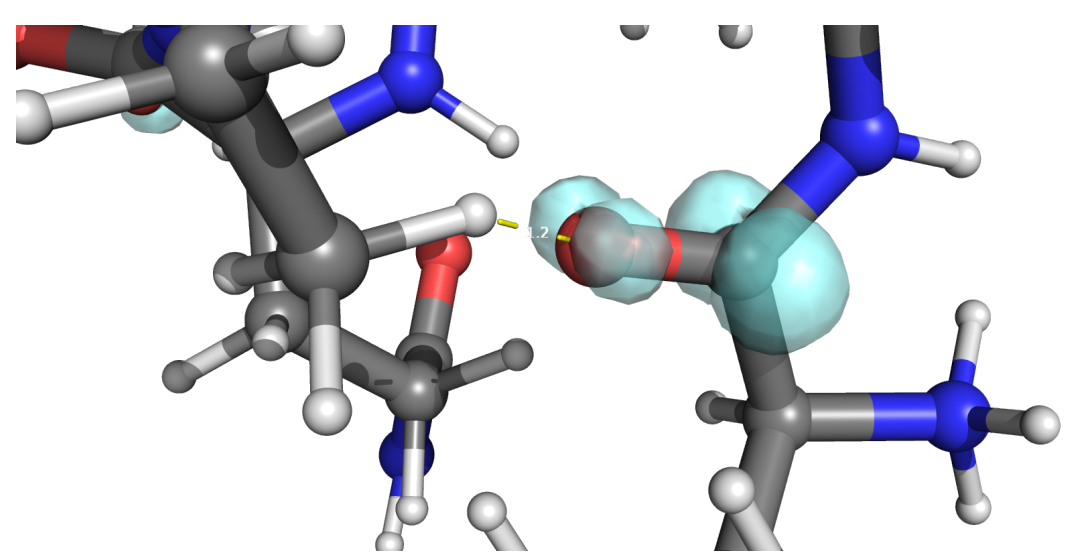

Figure S3: FOD plot calculated with GFN2-xTB at $\sigma=0.01 \mathrm{e} \mathrm{Bohr}^{-3}\left(\mathrm{~T}_{e l}=5000 \mathrm{~K}\right)$ for the critical part of the protein $100 J$.

Since all other metalloproteins with the same procedure led to a satisfactory result, a pre-optimization of this protein was omitted to preserve an unbiased statistics. Therefore, 1OOJ was excluded from the test set leading to a final metalloprotein test set of 20 proteins. For GFN1-xTB, four geometry optimization (for 1DXG, 1IAE, 4FWX and 4XPX) did not converge, which indicates that the additional terms included in GFN2-xTB are essential for its robustness, at least in the context of protein structure optimizations. 
Table S7: Properties of metalloproteins including the metal, the number (\#) the number of atoms and residues (res), charges, the percentage of secondary structure as $\alpha$-helix, $\beta$-strand, and unstructured loop region, the class of a peptide and protein as well as the $\mathrm{X}$-Ray resolution.

\begin{tabular}{|c|c|c|c|c|c|c|c|c|}
\hline $\begin{array}{l}\text { PDB metal } \\
\text { en- } \\
\text { try }\end{array}$ & \# atoms & \# res & charge & helix & strand & loop & class & $\begin{array}{l}\text { X-Ray } \\
\text { res }\end{array}$ \\
\hline 1DXG Fe & 1034 & 76 & -11 & 0 & 33.3 & 66.7 & $\begin{array}{l}\text { non-heme iron pro- } \\
\text { tein }\end{array}$ & 1.8 \\
\hline $1 \mathrm{~B} 7 \mathrm{~V} \mathrm{Fe}$ & 1081 & 81 & -6 & 53.5 & 0 & 46.5 & electron transfer & 1.7 \\
\hline $3 \mathrm{D} 2 \mathrm{~N} \mathrm{Zn}$ & 1209 & 78 & 4 & 15.8 & 10.5 & 73.7 & $\begin{array}{l}\text { metal binding, RNA } \\
\text { binding protein }\end{array}$ & 2.7 \\
\hline 1AG6 $\mathrm{Cu}$ & 1440 & 100 & -10 & 4 & 31.3 & 64.6 & electron transport & 1.6 \\
\hline 4CUE $\mathrm{Ca}$ & 1738 & 126 & -6 & 0 & 32.8 & 67.2 & transcription & 3 \\
\hline 4XPX Fe & 2027 & 134 & 1 & 71.5 & 0 & 28.5 & $\begin{array}{l}\text { oxygen binding pro- } \\
\text { tein }\end{array}$ & 1.03 \\
\hline $5 \mathrm{FTZ} \mathrm{Cu}$ & 2535 & 178 & 6 & 3.5 & 29.7 & 66.9 & lyase & 1.38 \\
\hline $4 \mathrm{FWXFe}$ & 2540 & 158 & 0 & 70.6 & 0 & 29.4 & transport protein & 1.9 \\
\hline 1NX2 Ca & 2782 & 188 & 1 & 60.7 & 2.3 & 37 & hydrolase & 2.2 \\
\hline 1IAC $\mathrm{Hg}$ & 3078 & 204 & -12 & 21.5 & 14 & 64.5 & zinc endopeptidase & 2.1 \\
\hline $1 \mathrm{AST} Z \mathrm{Zn}$ & 3084 & 206 & -12 & 19.5 & 14 & 66.5 & $\begin{array}{l}\text { hydrolase (metallo- } \\
\text { proteinase) }\end{array}$ & 1.8 \\
\hline 1IAA $\mathrm{Cu}$ & 3084 & 206 & -13 & 20 & 14 & 66 & zinc endopeptidase & 1.9 \\
\hline 1IAB Co & 3084 & 206 & -12 & 19.5 & 14 & 66.5 & zinc endopeptidase & 1.79 \\
\hline 1IAE $\mathrm{Ni}$ & 3090 & 208 & -12 & 19.5 & 14 & 66.5 & zinc endopeptidase & 1.83 \\
\hline 1QJJ Zn & 3129 & 210 & -11 & 19.2 & 12.3 & 68.5 & $\begin{array}{l}\text { hydrolase/hydrolase } \\
\text { inhibitor }\end{array}$ & 1.86 \\
\hline
\end{tabular}




\begin{tabular}{|c|c|c|c|c|c|c|c|c|}
\hline $1 \mathrm{EPT} \mathrm{Ca}$ & 3257 & 226 & 7 & 7.2 & 23.8 & 69.1 & hydrolase & 1.8 \\
\hline & & & & & & & protease) & \\
\hline $1 \mathrm{CON} \mathrm{Cd}$ & 3596 & 249 & 1 & 0 & 45.1 & 54.9 & lectin(agglutinin) & 2 \\
\hline \multicolumn{9}{|l|}{$\mathrm{Ca}$} \\
\hline $1 \mathrm{~A} 7 \mathrm{~V} \mathrm{Fe}$ & 3929 & 264 & 5 & 66.4 & 0 & 33.6 & electron transport & 2.3 \\
\hline 1BZM Zn & 4031 & 267 & 0 & 8.5 & 27.7 & 63.8 & lyase(oxo-acid) & 2 \\
\hline 1YMEZn & 4804 & 314 & 2 & 34.9 & 13.7 & 51.5 & carboxypeptidase & 1.53 \\
\hline
\end{tabular}

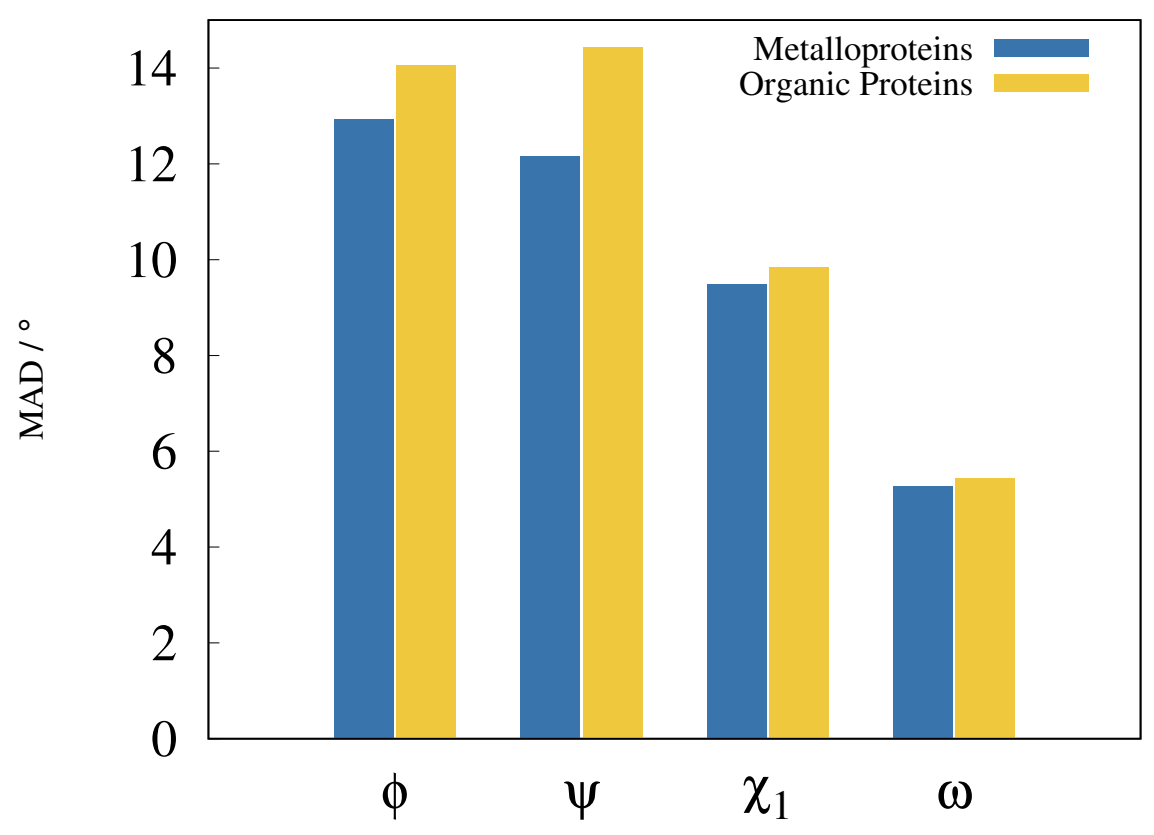

Figure S4: Average deviations of four types of dihedral angles of the first and second test set with respect to the crystal structure. 
Coordination sphere around metal centers

Table S7: Coordination numbers of the metals of the second test set and mean absolute error of the bond lengths between metal center and first ligands (in $\AA$ ). "case" refers to the discussed cases in the paper (section Results and Discussion - Metalloproteins - Coordination sphere around metal centers). On the bottom it is shown, how often the respecitve cases occur within the second test set.

\begin{tabular}{|c|c|c|c|c|c|c|}
\hline PDB entry & metal & metal number & $\mathrm{CN}_{X-r a y}$ & $\mathrm{CN}_{G F N 2-x T B}$ & MAE $[\AA]$ & case \\
\hline \multirow[t]{2}{*}{$1 \mathrm{~A} 7 \mathrm{~V}$} & $\mathrm{Fe}$ & 1885 & 5 & 5 & 0.05 & A \\
\hline & $\mathrm{Fe}$ & 1928 & 5 & 5 & 0.04 & A \\
\hline 1AG6 & $\mathrm{Cu}$ & 738 & 3 & 4 & 0.08 & B \\
\hline $1 \mathrm{AST}$ & $\mathrm{Zn}$ & 1592 & 4 & 5 & 0.06 & B \\
\hline $1 \mathrm{~B} 7 \mathrm{~V}$ & $\mathrm{Fe}$ & 539 & 6 & 6 & 0.11 & A \\
\hline 1BZM & $\mathrm{Zn}$ & 2035 & 4 & 4 & 0.07 & A \\
\hline \multirow[t]{3}{*}{$1 \mathrm{CON}$} & $\mathrm{Cd}$ & 1810 & 6 & 6 & 0.21 & A \\
\hline & $\mathrm{Ca}$ & 1811 & 6 & 5 & 0.20 & $\mathrm{D}$ \\
\hline & $\mathrm{Cd}$ & 1812 & 5 & 8 & 0.26 & D \\
\hline \multirow[t]{2}{*}{ 1DXG } & $\mathrm{Fe}$ & 523 & 4 & 4 & 0.15 & A \\
\hline & $\mathrm{Fe}$ & 524 & 4 & 6 & 0.04 & B \\
\hline $1 \mathrm{EPT}$ & $\mathrm{Ca}$ & 2032 & 5 & 5 & 0.23 & $\mathrm{C}$ \\
\hline 1IAA & $\mathrm{Cu}$ & 1592 & 5 & 4 & 0.11 & B \\
\hline $1 \mathrm{IAB}$ & Co & 1592 & 5 & 6 & 0.19 & $\mathrm{D}$ \\
\hline $1 \mathrm{IAC}$ & $\mathrm{Hg}$ & 1592 & 3 & 5 & 0.23 & $\mathrm{D}$ \\
\hline $1 \mathrm{IAE}$ & $\mathrm{Ni}$ & 1592 & 6 & 6 & 0.24 & A \\
\hline \multirow[t]{4}{*}{ 1NX2 } & $\mathrm{Ca}$ & 1396 & 4 & 5 & 0.20 & $\mathrm{~B}, \mathrm{C}, \mathrm{D}$ \\
\hline & $\mathrm{Ca}$ & 1397 & 4 & 6 & 0.15 & $\mathrm{~B}, \mathrm{D}$ \\
\hline & $\mathrm{Ca}$ & 1398 & 6 & 5 & 0.49 & $\mathrm{~B}, \mathrm{C}, \mathrm{D}$ \\
\hline & $\mathrm{Ca}$ & 1399 & 5 & 4 & 0.23 & B \\
\hline 1QJJ & $\mathrm{Zn}$ & 1954 & 5 & 6 & 0.07 & B \\
\hline $1 \mathrm{YME}$ & $\mathrm{Zn}$ & 2437 & 5 & 5 & 0.11 & A \\
\hline \multirow[t]{2}{*}{$3 \mathrm{D} 2 \mathrm{~N}$} & $\mathrm{Zn}$ & 611 & 4 & 4 & 0.09 & A \\
\hline & $\mathrm{Zn}$ & 612 & 4 & 4 & 0.12 & A \\
\hline \multirow[t]{3}{*}{ 4CUE } & $\mathrm{Ca}$ & 915 & 5 & 4 & 0.31 & C,D \\
\hline & $\mathrm{Ca}$ & 916 & 5 & 4 & 0.10 & C,D \\
\hline & $\mathrm{Ca}$ & 917 & 5 & 5 & 0.16 & C,D \\
\hline $4 \mathrm{FWX}$ & $\mathrm{Fe}$ & 1262 & 6 & 6 & 0.05 & A \\
\hline \multirow[t]{2}{*}{ 4XPX } & $\mathrm{Fe}$ & 1026 & 6 & 6 & 0.15 & A \\
\hline & $\mathrm{Fe}$ & 1027 & 6 & 6 & 0.15 & A \\
\hline \multirow[t]{2}{*}{$5 \mathrm{FTZ}$} & $\mathrm{Cu}$ & 1305 & 2 & 4 & 0.08 & $\mathrm{~B}, \mathrm{D}$ \\
\hline & $\mathrm{Cu}$ & 1306 & 2 & 4 & 0.15 & $\mathrm{~B}, \mathrm{D}$ \\
\hline A: & 13 & & & & & \\
\hline B: & 6 & & & & & \\
\hline C: & 1 & & & & & \\
\hline D: & 4 & & & & & \\
\hline mixed: & 8 & & & & & \\
\hline
\end{tabular}




\section{Results for GFN1-xTB - Metalloproteins}

GFN2-xTB is for all geometrical descriptors better than GFN1-xTB. Nevertheless, the deviations between GFN1-xTB optimized and corresponding X-ray structures are reasonably small. For GFN1-xTB, statistical data is obtained for the presented test set excluding the four proteins, for which GFN1-xTB showed convergence problems during optimization.

Table S8: Average deviations of four types of dihedral angles (in degree) of the second test set with respect to the crystal structure as well as average $C_{\alpha}$ and heavy atoms RMSD (in $\AA$ ).

\begin{tabular}{l|c} 
& GFN1-xTB \\
\hline$\Delta \Phi$ & 14.05 \\
$\Delta \Phi$ & 13.60 \\
$\Delta \chi_{1}$ & 10.11 \\
$\Delta \omega$ & 6.86 \\
$\mathrm{C}_{\alpha}$ & 0.88 \\
heavy atoms & 1.07
\end{tabular}

\section{Conversion of files}

The Mercury program package ${ }^{3}$ was used to convert Schrödinger PDB files into cif files. Furthermore, openbabel ${ }^{4,5}$ was used to convert xyz files of the GFNn-xTB and HF-3c calculations to PDB files in order to determine the dihedral angles and the $C_{\alpha}$ atoms.

\section{References}

(1) Grimme, S.; Hansen, A. A Practicable Real-Space Measure and Visualization of Static Electron-Correlation Effects. Angewandte Chemie International Edition 2015, $54,12308-12313$.

(2) Bauer, C. A.; Hansen, A.; Grimme, S. The Fractional Occupation Number Weighted Density as a Versatile Analysis Tool for Molecules with a Complicated Electronic Structure. Chemistry - A European Journal 2017, 23, 6150-6164. 
(3) Mercury CSD 2.0 - new features for the visualization and investigation of crystal structuresd.

(4) O’Boyle, N. M.; Banck, M.; James, C., Craig A.and Morley; Vandermeersch, T.; Hutchison, G. R. Open Babel: An open chemical toolbox. Journal of Cheminformatics 2011, 3, 33 .

(5) The Open Babel Package, version 2.3.1 http://openbabel.org (accessed Feb 2018). 